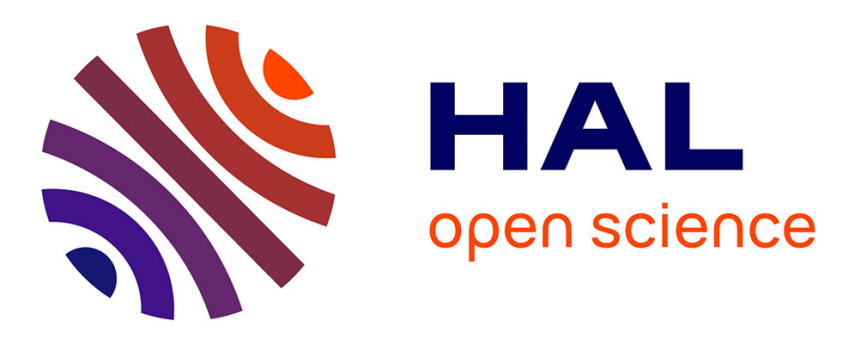

\title{
Zinc distribution and speciation in roots of various genotypes of tobacco exposed to $\mathrm{Zn}$
}

Anne Straczek, Geraldine Sarret, Alain Manceau, Philippe Hinsinger, Nicolas

Geoffroy, Benoit Jaillard

\section{- To cite this version:}

Anne Straczek, Geraldine Sarret, Alain Manceau, Philippe Hinsinger, Nicolas Geoffroy, et al.. Zinc distribution and speciation in roots of various genotypes of tobacco exposed to Zn. Environmental and Experimental Botany, 2008, 63, pp.80-90. hal-00311796

\section{HAL Id: hal-00311796 \\ https://hal.science/hal-00311796}

Submitted on 21 Aug 2008

HAL is a multi-disciplinary open access archive for the deposit and dissemination of scientific research documents, whether they are published or not. The documents may come from teaching and research institutions in France or abroad, or from public or private research centers.
L'archive ouverte pluridisciplinaire HAL, est destinée au dépôt et à la diffusion de documents scientifiques de niveau recherche, publiés ou non, émanant des établissements d'enseignement et de recherche français ou étrangers, des laboratoires publics ou privés. 
1 Full title: Zinc distribution and speciation in roots of various genotypes of tobacco

2 exposed to Zn Environmental \& Experimental Botany, 2008, 63, 80-90

3

4 Author's names Anne STRACZEK ${ }^{1}$, Géraldine SARRET ${ }^{2}$, Alain MANCEAU ${ }^{2}$, Philippe

5 HINSINGER $^{1}$ and Benoît JAILLARD ${ }^{1}$

6 (1) UMR 1222 Agro.M - INRA Rhizosphère \& Symbiose, 2 place Pierre Viala, 34060

7 Montpellier cedex 2, France.

8 (2) Environmental Geochemistry Group, LGIT, University of Grenoble and CNRS, BP 53, 938041 Grenoble Cedex 9, France.

12 Editorial correspondence : annestraczek@yahoo.fr, UMR 1222 Agro.M - INRA Rhizosphère

13 \& Symbiose, 2 place Pierre Viala, 34060 Montpellier cedex 2, France, FAX: 0033499613

14 088Abstract

15 Cell walls of roots have a great reactivity towards metals, and may act as a barrier limiting the

16 entry of metals, especially in non hyperaccumulating species. The aim of this study was to

17 determine the localization and speciation of $\mathrm{Zn}$ in roots of tobacco (Nicotiana tabacum)

18 grown in Zn-contaminated substrates. Chemical extractions and EXAFS spectroscopy were

19 applied on whole roots and on isolated cell walls of roots. Our results show that cell walls of

20 roots exhibited a distribution of $\mathrm{Zn}$ affinity sites, from water-soluble to non- exchangeable $\mathrm{Zn}$.

21 In whole roots, $\mathrm{Zn}$ was bound with oxalate and other $\mathrm{COOH} / \mathrm{OH}$ groups: the first species was

22 probably intracellular while the second was attributed to $\mathrm{Zn}$ bound to the cell walls and, to a

23 lesser extent, to intracellular organic acids. Moreover, $\mathrm{Zn}$ phosphate was also identified, and

24 this species was $\mathrm{CuSO}_{4}$-extractable. It probably resulted from chemical precipitation in the

25 apoplasm, and explained the steady increase in exchangeable root $\mathrm{Zn}$ observed in root of 
26 tobacco during the culture. This study shows the strength of combining EXAFS and chemical

27 extractions for studying localization and speciation of metals in plants.

28

\section{Keywords}

30 Cation Exchange Capacity of Roots (CECR), Cell walls, chemical extractions, EXAFS,

31 pectin, cellulose

32

Abbreviations

A1, control genotype of tobacco (wild-type genotype neutrally transformed with a CAMV 35S promoter-GUS construct);

CaMV, cauliflower mosaic virus;

CECR, cation exchange capacity of roots;

C5, genotype of tobacco genetically transformed to over-accumulate the Fe storage protein ferritin in the cytoplasm;

EDTA, ethylene-diamine-tetra-acetic acid;

ESRF, European Synchrotron Radiation Facility;

EXAFS, extended X-ray absorption fine structure;

NSS, normalized sum-squares; 


\section{1}

52

53

54

55

56

57

58

59

60

61

62

63

64

65

66

67

68

69

\section{Introduction}

Numerous authors (e.g. Haynes, 1980; Sattelmacher, 2001) have shown that the cell walls of plant roots are involved in the acquisition of mineral elements. This compartment also plays a role in metal tolerance by acting as a barrier for some elements (Ernst et al., 1992). Main components of plant cell walls are cellulose, hemicellulose, pectin and glycoproteins. The cation exchange capacity of roots (CECR) arises mostly from carboxyl and hydroxyl groups, and to a minor extent from phenolic and amine groups (Meychik et al., 2001). The structure and the composition of the cell walls (and consequently the CECR) vary as a function of the plant species, of its nutrition and of the age of the plant tissues.

Particularly, the development of secondary cell walls in older tissues induces a decrease in CECR because of the lower pectin and higher lignin content of this structure. The CECR ranges between 10 and $20 \mathrm{cmol}_{\mathrm{c}} \mathrm{kg}^{-1}$ (or meq $100 \mathrm{~g}^{-1}$ ) for monocot species and between 20 and $50 \mathrm{cmol}_{\mathrm{c}} \mathrm{kg}^{-1}$ for dicot species (Dufey et al., 2001). The affinity of cations for exchangeable sites on root cell walls decreases in the order $\mathrm{H}>\mathrm{Cu}>\mathrm{Ca}>\mathrm{Zn}$ according to Nishizono et al. (1987), and $\mathrm{H}>\mathrm{Cu}>\mathrm{Zn}>\mathrm{Ca}$ according to Ernst et al. (1992). A similar order of affinity was found for pectin (Franco et al., 2002). Based on the high affinity of $\mathrm{Cu}$ for the cell walls, Dufey and Braun (1986) showed that saturating the cell walls with $\mathrm{Cu}$, and then extracting it using $\mathrm{HCl}$, was an easy and reliable way to measure the CECR because they obtained comparable CECR values by this method and by acid-base titration of roots.

An overview of the literature shows a great variability in $\mathrm{Zn}$ localization and exchangeability in plants roots: exchangeable $\mathrm{Zn}$ represented $10 \%$ of total root $\mathrm{Zn}$ in Silene vulgaris (Harmens et al., 1993), 16\% in wheat (Triticum aestivum) and 46\% in soybean (Glycine max) (Steveninck et al., 1993), 27\% in barley (Hordeum vulgare) (Wu et al., 2005), $60 \%$ in the hyperaccumulator Thlaspi caerulescens (Lasat et al., 1998), and 67 to $87 \%$ in the Zn-tolerant fern Athyrium yokoscense (Nishizono et al., 1987). This wide range of responses 
may result from actual differences between species, but also from the techniques used for measuring the so called "exchangeable" Zn (isolation of cell walls, chemical extractions, isotopic exchange, transmission electron microscopy coupled with energy dispersive X-ray microanalysis, etc...). Other possible sources of differences include the duration and intensity of $\mathrm{Zn}$ exposure (Vasquez et al., 1994), and the age of the plants.

Although zinc has a high affinity for cell walls, there is no consensus on the stability of Zn-root cell wall complexes. Nishizono et al. (1987) showed that $\mathrm{Zn}$ associated to isolated root cell walls of Athyrium yokoscence was totally exchangeable. Lasat et al. (1998) found that exchangeable $\mathrm{Zn}$ represented the majority (but not all) of apoplasmic $\mathrm{Zn}$ in the roots of Thlaspi caerulescens. Similarly, Hart et al. (1998) found a small proportion of strongly bound Zn (i.e., non exchangeable) on cell walls of wheat roots.

7 Extended X-ray absorption fine structure (EXAFS) spectroscopy is well adapted for the study of metal speciation in plant samples because it is an element-specific probe sensitive to the short-range order (Salt et al., 2002). The main limitation of bulk EXAFS is that it provides averaged information. For instance, the spectrum for whole roots would contain averaged contribution of the different cell compartments (apoplasm, symplasm, etc...), and it may be difficult to isolate them and to obtain structural information on each one. Combining this spectroscopic method with chemical extractions could be a way to overcome this limitation. In this study, the distribution and the speciation of $\mathrm{Zn}$ in roots of tobacco was studied by a purely chemical approach and a purely (Zn K-edge EXAFS) spectroscopic approach which was conducted on whole roots and on isolated cell walls of roots, and a combination of chemical approach and EXAFS spectroscopic approach on whole roots.

9 Material and methods

Plant material and preculture of tobacco 
101 The plant materials were two genotypes of tobacco (Nicotiana tabacum $\mathrm{cv} S R$ ). A control

102 genotype (A1) was a wild-type genotype transformed with a CAMV 35S promoter-GUS

103 construct without any gene insert. The other genotype (C5) was genetically transformed to

104 over-accumulate ferritin in the cytosol (van Wuytswinkel et al., 1999). Ferritin is an iron

105 storage protein naturally present in plants. Animal ferritins are known to bind Zn (Briat and

106 Lebrun, 1999), whereas this has not been demonstrated for plant ferritins.

107 Seeds were surface sterilised with $\mathrm{NaOCl}$ for $25 \mathrm{~min}$, then carefully washed with sterile

108 water. Plants were cultivated in a cropping device designed to easily separate the roots from

109 the growing soil at harvest (Niebes et al., 1993). The plant container was made of a PVC

110 cylinder (inner diameter $40 \mathrm{~mm}$ ) closed at the bottom by a fine polyamide mesh $(30 \mu \mathrm{m}$ pore

111 diameter, Sefar Nytel/Fyltis). For the preculture, plant containers were placed on a nutrient

112 gel in sterile and capped cropping boxes $(150 \times 150 \times 135 \mathrm{~mm}$, MERCK eurolab, Polylabo).

113 The nutrient gel was prepared by adding $1.0 \mathrm{~g} \mathrm{~L}^{-1}$ gelrite (Sigma G1910) and $0.6 \mathrm{~g} \mathrm{~L}^{-1}$

114 phytagel (Sigma P8169) to a Hoagland solution containing $5 \mathrm{mM} \mathrm{KNO}_{3}, 5 \mathrm{mM} \mathrm{Ca}\left(\mathrm{NO}_{3}\right)_{2}, 2$

$115 \mathrm{mM} \mathrm{MgSO}_{4}, 1 \mathrm{mM} \mathrm{KH}_{2} \mathrm{PO}_{4}, 50 \mu \mathrm{M} \mathrm{H}_{3} \mathrm{BO}_{3}, 50 \mu \mathrm{M} \mathrm{MnSO}_{4}, 50 \mu \mathrm{M}$ Fe-EDTA, $15 \mu \mathrm{M}$

$116 \mathrm{ZnSO}_{4}, 3 \mu \mathrm{M}\left(\mathrm{NH}_{4}\right) \mathrm{MoO}_{4}, 2.5 \mu \mathrm{M} \mathrm{KI}, 50 \mathrm{nM} \mathrm{CoCl}_{2}$, and $50 \mathrm{nM} \mathrm{CuSO}_{4}$. Five seeds were put

117 in each plant container, and each cropping box contained 9 containers. Boxes were placed in a

118 growth chamber with a $16 / 8 \mathrm{~h}$ day/night cycle, light intensity of $250 \mu \mathrm{mol}$ photons $\mathrm{m}^{-2} \mathrm{~s}^{-1}$,

119 temperature of $23 / 20^{\circ} \mathrm{C}$ and $75 / 80 \%$ relative humidity. After two weeks, the cropping boxes

120 were progressively opened for 3 days so that plants could adapt to ambient culture conditions.

121 The containers were then transferred in a nutrient solution containing $1 \mathrm{mM} \mathrm{KNO} \mathrm{m}_{3}, 1 \mathrm{mM}$

$122 \mathrm{Ca}\left(\mathrm{NO}_{3}\right)_{2}, 0.5 \mathrm{mM} \mathrm{MgSO}_{4}, 20 \mu \mathrm{M}$ Fe-EDTA, $10 \mu \mathrm{M} \mathrm{H}_{3} \mathrm{BO}_{3}, 5 \mu \mathrm{M} \mathrm{KH}_{2} \mathrm{PO}_{4}, 2 \mu \mathrm{M} \mathrm{MnCl}_{2}$,

$1230.5 \mu \mathrm{M} \mathrm{MoNaO}_{4}, 0.5 \mu \mathrm{M} \mathrm{ZnSO}_{4}$ and $0.2 \mu \mathrm{M} \mathrm{CuCl}_{2}$ (10 plant containers per $5 \mathrm{~L}$ bucket). The

124 solution was renewed weekly. After two weeks, the plants were then 4-week old, and each 
125 container presented a homogeneous root mat formed by the roots of 5 plants. The $\mathrm{pH}$ of the

126 nutrient solution was between 5.5 and 6.1.

127

128 Culture of tobacco in hydroponics

129 All culture conditions are summarized in Table 1. For the measurement of the CECR (culture

$130 \mathrm{n}^{\circ} 1$ ), plant containers containing 4-week old plants (A1 and C5 genotype) were transferred in

131 a nutrient solution devoid of $\mathrm{Fe}$, and containing $100 \mu \mathrm{M} \mathrm{ZnSO}_{4}, 1 \mathrm{mM} \mathrm{KNO}{ }_{3}, 1 \mathrm{mM}$

$132 \mathrm{Ca}\left(\mathrm{NO}_{3}\right)_{2}, 0.5 \mathrm{mM} \mathrm{MgSO}_{4}, 10 \mu \mathrm{M} \mathrm{H}_{3} \mathrm{BO}_{3}, 5 \mu \mathrm{M} \mathrm{KH}_{2} \mathrm{PO}_{4}, 2 \mu \mathrm{M} \mathrm{MnCl}_{2}, 0.5 \mu \mathrm{M} \mathrm{MoNaO}$,

133 and $0.2 \mu \mathrm{M} \mathrm{CuCl}_{2}$. Note that $\mathrm{P}$ concentration was low $(5 \mu \mathrm{M})$ to avoid precipitations with $\mathrm{Zn}$,

134 as predicted by the SOILCHEM speciation code (Sposito and Coves, 1988). Plants were

135 grown for 2, 4, 7 and 14 days (8 plant containers per $5 \mathrm{~L}$ bucket). The $\mathrm{pH}$ of the solution was

1365.5 at the beginning of culture.

137 For the comparison of the sequential extraction procedures, 4-week old plants (A1

138 genotype) were grown in the same conditions for 4 days (culture $\left.n^{\circ} 2\right)$. For the EXAFS

139 analyses, 4-week old plants (C5 genotype) were grown in the same conditions except $\mathrm{Zn}$

140 concentration $\left(200 \mu \mathrm{M}\right.$ instead of $\left.100 \mu \mathrm{M} \mathrm{ZnSO}_{4}\right)$ for 4 days (culture $\left.{ }^{\circ} 3\right)$. No toxicity

141 symptoms were observed in any culture, probably due to the presence of $\mathrm{Ca}$ in the nutrient

142 medium which partially alleviates Zn toxicity in tobacco (Sarret et al., 2006).

144 Culture of tobacco on artificial substrates (culture $\mathrm{n}^{\circ} 4$ )

145 Artificial substrates were made of agarose nutrient gel containing various $\mathrm{Zn}$-bearing minerals

146 to provide a range of $\mathrm{Zn}$ availabilities with in spite of an identical total $\mathrm{Zn}$ content in the

147 substrates. The nutrient solution contained $1 \mathrm{mM} \mathrm{KNO}_{3}, 0.625 \mathrm{mM} \mathrm{Ca}\left(\mathrm{NO}_{3}\right)_{2}, 0.5 \mathrm{mM}$

$148 \mathrm{MgSO}_{4}, 0.375 \mathrm{mM}\left(\mathrm{NH}_{4}\right)_{2} \mathrm{SO}_{4}, 10 \mu \mathrm{M} \mathrm{H}_{3} \mathrm{BO}_{3}, 5 \mu \mathrm{M} \mathrm{KH}_{2} \mathrm{PO}_{4}, 2 \mu \mathrm{M} \mathrm{MnCl}{ }_{2} \cdot \mathrm{H}_{2} \mathrm{O}, 0.5 \mu \mathrm{M}$

$149 \mathrm{MoNaO}_{4} \cdot 2 \mathrm{H}_{2} \mathrm{O}$, and $0.2 \mu \mathrm{M} \mathrm{CuCl}_{2}$. Zn-bearing minerals included $\mathrm{Zn}$-sorbed synthetic 
150 ferrihydrite and $\mathrm{Zn}$-sorbed hectorite containing $0.2 \%$ dry weight $\mathrm{Zn}$. Ferrihydrite is a poorly

151 crystalline iron oxyhydroxide with a high sorption capacity, and hectorite (SHCa-1 from the

152 Source Clay Repository of the Clay Minerals Society) is a magnesian smectite composed of

153 an octahedral sheet of magnesium sandwiched between two tetrahedral sheets of silicon. The

154 substrates contained $49 \mathrm{~g} \mathrm{~L}^{-1}$ of $\mathrm{Zn}$-sorbed ferrihydrite or hectorite, and $10 \mathrm{~g} \mathrm{~L}^{-1}$ of agarose.

155 A control culture substrate was made with agarose only, the nutrient solution being

156 supplemented with $1500 \mu \mathrm{M} \mathrm{ZnSO}_{4}$. Note that a fraction of added $\mathrm{Zn}$ is finally adsorbed on

157 agarose gel (Calba et al, 1999). Four-week old plants (A1 and C5 genotypes) were grown for

1584 days on Zn-ferrihydrite, Zn-hectorite and Zn-agarose substrates (Table 1). Table 2 shows

159 that $\mathrm{Zn}$ root concentrations increased in the order hectorite $<$ ferrihydrite $<$ agarose. At the

160 end of the culture, shoots and roots were harvested separately and stored for further chemical

161 and EXAFS analyses.

162

163 Extraction of cell walls of roots of tobacco

164 Fresh roots of 4-week old A1 genotype tobacco were harvested and then immersed in a $1 \%$

165 v:v Triton X100 detergent solution with $1 \mathrm{mM} \mathrm{CaCl}_{2}$ to dissolve the cell content (Calba et al., 166 1999). The detergent solution was renewed periodically for 28 days. The detergent was then

167 removed by washing the material for 15 days with a $1 \mathrm{mM} \mathrm{CaCl}_{2}$ solution. The entire

168 treatment was carried out at $4^{\circ} \mathrm{C}$.

169 Zinc-cell wall complexes were conditioned prior to sequential extractions as follows.

170 Three $g$ of cell walls were placed in $1 \mathrm{~L}$ of nutrient solution (the same as the one used for the

171 hydroponic culture without Fe-EDTA) containing $100 \mu \mathrm{M} \mathrm{ZnSO}_{4}$, then shaken end over end

172 for 24 hours. Other Zn-cell wall complexes were prepared for EXAFS analysis (see the

173 EXAFS section). 
175

176

177

178

179

180

181

182

183

184

185

186

187

190

191

192

193

194

\section{Sequential extractions of whole roots and isolated cell walls of roots of tobacco}

The CECR was determined by sequential extractions by adapting the procedure of Dufey and Braun (1986). Roots of A 1 and C5 genotype tobacco plants from culture $\mathrm{n}^{\circ} 1$ were harvested. Each root sample was made of the roots of 5 plants grown in the same container. An aliquot was oven dried at $105^{\circ} \mathrm{C}$, digested and analyzed for total $\mathrm{Zn}$. The remainder $(25 \mathrm{mg} \pm 8 \mathrm{mg}$ dry weight) was shaken end over end in $5 \mathrm{~mL}$ of $10 \mathrm{mM} \mathrm{CuSO}_{4}$ during $30 \mathrm{~min}$. The initial $\mathrm{pH}$ of the solution was 4.8. The suspension was then filtered, and $\mathrm{Ca}$ and $\mathrm{Zn}$ concentration in the filtrate were measured. Copper is supposed to displace all cations associated to the cell walls and to saturate the CECR. The roots were then briefly rinsed with a solution containing $0.1 \mathrm{mM} \mathrm{CuSO}_{4}$ to reduce the excess $\mathrm{Cu}$ in the interstitial volume of roots before to be shaken end over end in $50 \mathrm{~mL}$ of $100 \mathrm{mM} \mathrm{HCl}$ during $20 \mathrm{~min}$ to extract $\mathrm{Cu}$, the suspension was filtered, and $\mathrm{Cu}$ concentration in the filtrate was measured. The acidic extraction is supposed to desorb $\mathrm{Cu}$ from the cell walls. The CECR was thus estimated from the amount of desorbed $\mathrm{Cu}$, by considering $\mathrm{Cu}$ as a divalent cation.

Sequential extractions were performed on whole roots of A1 tobacco from culture $n^{\circ} 2$

(Table 1) and on isolated cell walls. Samples (22 $\mathrm{mg} \pm 7 \mathrm{mg}$ dry weight for roots and $32 \mathrm{mg} \pm$ $5 \mathrm{mg}$ dry weight for cell walls) were treated with $10 \mathrm{mM} \mathrm{CuSO}_{4}$, then $100 \mathrm{mM} \mathrm{HCl}$ as described above. This procedure was realized at $25^{\circ} \mathrm{C}$ and at $4{ }^{\circ} \mathrm{C}$. Other extraction procedures were tested at both temperatures. The first one involved three successive extractions in 10 $\mathrm{mM} \mathrm{CuSO}_{4}$ during $30 \mathrm{~min}$, and then an extraction in $50 \mathrm{~mL}$ of $100 \mathrm{mM} \mathrm{HCl}$ during $20 \mathrm{~min}$. The second one involved an extraction in $5 \mathrm{~mL}$ ultra pure water during 2 hours, followed by an extraction in $5 \mathrm{~mL}$ of $10 \mathrm{mM} \mathrm{CaCl}_{2}$ during 2 hours. The third one involved an extraction in $50 \mathrm{~mL}$ of $10 \mathrm{mM}$ EDTA pH 7 during 2 hours. For all procedures, after each extraction, the root suspension was filtered over an ashless filter paper (Whatman 40), and elemental concentrations were determined in the filtrate and in the extracted roots. 
Roots of C5 genotype tobacco from culture $n^{\circ} 3$ (Table 1) were treated at $25^{\circ} \mathrm{C}$

201 following the $\mathrm{CuSO}_{4} / \mathrm{HCl}$ procedure, and aliquots of non-extracted, $\mathrm{CuSO}_{4}$-extracted and

$202 \mathrm{CuSO}_{4} / \mathrm{HCl}$-extracted roots were kept for EXAFS analyses.

203

204 Chemical analyses of plants and solutions

205 Samples (shoots, whole roots, isolated cell walls of roots and root residues after extractions

206 depending on the experiment) were weighed, oven-dried at $105^{\circ} \mathrm{C}$ and digested in a $1: 1$

207 mixture of hot concentrated $\mathrm{HNO}_{3}$ and $\mathrm{HClO}_{4}$ (A.O.A.C., 1975). Ca, $\mathrm{Zn}$ and $\mathrm{Cu}$

208 concentrations were determined in the digests and in the filtrates of the chemical extractions

209 by flame atomic absorption spectrometry (Varian SpectrAA-600, Australia). Malate, citrate

210 and oxalate concentrations were measured in the roots of A1 genotype tobacco at the end of

211 the preculture (4-week old plants). One g of fresh roots was put in $10 \mathrm{~mL}$ of $\mathrm{HCl} 100 \mathrm{mM}$ at

$21260^{\circ} \mathrm{C}$. After $20 \mathrm{~min}$, solution was filtered over an ashless filter paper (Whatman 40) and the

213 supernatant was analyzed by High Pressure Ionic Chromatography (Dionex 4,000) using an

214 AS11 column. The elution was performed with a $\mathrm{NaOH}$ gradient, and the signal was detected

215 by conductimetry, and analyzed with a integrator Chromjet (Spectra-Physics) integrator.

216 For each analysis, four replicates were prepared and analyzed. All results are expressed

217 relative to dry weight. Statistical analysis was performed using the ANOVA procedure with

218 the test of least significant difference (LSD, $\mathrm{p}=0.05$ ) of the Statistica Software (Statsoft Inc.).

220 Zn K-edge EXAFS spectroscopy

$221 \quad$ Zn model compounds

222 A variety of Zn-model compounds were used for the EXAFS data analysis. Zn-oxalate

223 dihydrate and Zn-citrate dihydrate were purchased from Alfa (Berkshire, UK). The

224 preparation of Zn-malate and Zn-sorbed hydroxylapatite were described previously (Sarret et 
225

226

227

228

229

230

231

232 For the Zn-cellulose complexes, $200 \mathrm{mg}$ of cellulose (Sigma-Aldrich) were suspended in 60

al., 2002; Panfili et al., 2005). The Zn-cysteine spectrum was provided by S. Beauchemin (Beauchemin et al. 2004). The Zn-cell wall complexes containing 0.75, 1.4, 12.7 and 69.6 $\mathrm{mmol} \mathrm{kg}{ }^{-1}$ d.w. Zn were prepared by placing $100 \mathrm{mg}$ (dry weight) of isolated cell walls of roots in $50 \mathrm{~mL}$ of $1.5,6.1,30.3$ and $303 \mu \mathrm{M} \mathrm{Zn}\left(\mathrm{NO}_{3}\right)_{2}$ at $\mathrm{pH} 5.0$, respectively, and shaking end over end for 24 hours. Final $\mathrm{pH}$ values were 5.0, 5.4, 5.4, and 5.4, respectively. The suspensions were then centrifuged, and the $\mathrm{Zn}$ loading was determined by difference between initial and supernatant $\mathrm{Zn}$ concentrations. $\mathrm{mL}$ of water and the $\mathrm{pH}$ was adjusted to 5.0. Two samples were prepared : after addition of 1 and $2 \mathrm{~mL}$ of $1.53 \mathrm{mM} \mathrm{Zn}\left(\mathrm{NO}_{3}\right)_{2}$ at $\mathrm{pH} 5.0$, respectively, the suspensions were stirred during 3 hours at fixed $\mathrm{pH} 5.0$ by adding $0.5 \mathrm{M} \mathrm{NaOH}$ or $\mathrm{HNO}_{3}$, then centrifuged. The $\mathrm{Zn}$ content in the $\mathrm{Zn}$-cellulose complexes was calculated as the difference between the amount of $\mathrm{Zn}$

237 introduced and the amount of $\mathrm{Zn}$ measured in the supernatant: they were 1.27 and $3.82 \mathrm{mmol}$ $238 \mathrm{~kg}^{-1}$ d.w. Zn. For each Zn concentration, half of the Zn-cellulose samples was freeze-dried, 239 and half was kept in wet state for EXAFS analysis. For the Zn-pectin complexes, $166 \mathrm{mg}$ of 240 pectin extracted from apples esterified at 70 to $75 \%$ (Fluka) were dissolved in $30 \mathrm{~mL}$ of 241 water, and the $\mathrm{pH}$ was adjusted to 5.0. Two samples were prepared : after addition of 0.4 and $0.9 \mathrm{~mL}$ of $4.31 \mathrm{mM} \mathrm{Zn}\left(\mathrm{NO}_{3}\right)_{2}$ at $\mathrm{pH} 5.0$, respectively, the suspensions were stirred during 3

243 hours at fixed $\mathrm{pH} 5.0$ by adding $0.5 \mathrm{M} \mathrm{NaOH}$ or $\mathrm{HNO}_{3}$. The $\mathrm{Zn}$-pectin complexes were

244 directly freeze-dried because they could not be concentrated by centrifugation. $\mathrm{Zn}$

245 concentrations were 15.29 and $7.65 \mathrm{mmol} \mathrm{kg}^{-1}$ d.w. of pectin, respectively.

\section{EXAFS data acquisition and treatment}

248 Zinc K-edge EXAFS analyses were performed on untreated whole roots of A1 and C5

249 genotype tobacco grown for 4 days on artificial substrates as described above (culture ${ }^{\circ} 4$ ), 
250 and on whole roots of C5 genotype tobacco grown for 4 days in $200 \mu \mathrm{M} \mathrm{Zn}$, untreated and

251 treated by chemical extractions (culture $n^{\circ} 3$ ). After harvesting, root samples were freeze-

252 dried, ground and pressed as pellets. EXAFS experiments were performed on beamlines

253 BM32 and FAME at the European Synchrotron Radiation Facility (ESRF, Grenoble, France)

254 in transmission mode for the references, and in fluorescence mode using a 30-element solid-

255 state Ge detector (Canberra) for the root samples. The great sensitivity of the spectrometer

256 made it possible to study samples containing down to $0.76 \mathrm{mmol} \mathrm{Zn} \mathrm{kg}^{-1}$ dry weight. EXAFS

257 data extraction was performed according to standard methods. Spectra were simulated by

258 linear combination fits using a library of $\mathrm{Zn}$ reference compounds, including $\mathrm{Zn}$ complexed to

259 simple organic acids and amino acids, cellulose, pectin, and isolated cell walls of roots, and

260 mineral and organic Zn-phosphate compounds (Guiné et al., 2006). For the first shell

261 simulation, EXAFS spectra were Fourier transformed, and the contribution of the first

262 coordination shell was simulated in $k$ and $R$ space. Theoretical functions for the $\mathrm{Zn}-\mathrm{O}$ and $\mathrm{Zn}$ -

263 S pair were calculated by FEFF7 (Rehr et al., 1991) from the structure of Zn-malate dihydrate

264 (Reed and Karipides, 1976) and sphalerite (Jumpertz, 1955) respectively.

\section{Results}

268 Accumulation of $\mathrm{Zn}$ in tobacco

269 In culture ${ }^{\circ} 1, \mathrm{~A} 1$ and $\mathrm{C} 5$ genotypes of tobacco were cultivated in hydroponics without $\mathrm{Fe}$

270 and with $100 \mu \mathrm{M} \mathrm{Zn}$. After 14 days of culture, total $\mathrm{Zn}$ uptake and $\mathrm{Zn}$ shoot content were

271 comparable for both genotypes: total uptakes were $1.1 \pm 0.2$ and $1.3 \pm 0.2 \mu \mathrm{mol} \mathrm{Zn}$ per A1

272 and C5 plants, and shoot contents were $15.1 \pm 1.7$ and $15.9 \pm 1.6 \mu \mathrm{mol} \mathrm{Zn} \mathrm{per} \mathrm{g,} \mathrm{respectively.}$

273 At the opposite, the $\mathrm{Zn}$ concentration of roots was larger for the ferritin overexpressor (98.8 \pm

$\left.2745.2 \mu \mathrm{mol} \mathrm{g}^{-1}\right)$ than for the wild type $\left(73.5 \pm 5.8 \mu \mathrm{mol} \mathrm{g}{ }^{-1}\right)$. For both genotypes, the $\mathrm{pH}$ of the 
275

276

277

278

279

280

281

282

283

284

285

286

287

288

289

290

291

292

293

294

295

296 297 tobacco.

nutrient solution increased from 5.5 at the beginning, to $6.0 \pm 0.1$ after two days and to $7.0 \pm$ 0.1 after 14 days of culture. The calculation of $\mathrm{Zn}$ speciation with SOILCHEM (Sposito and Coves, 1988) suggests a minor precipitation at $\mathrm{pH}$ 7.0: At $\mathrm{pH}$ 5.5, calculated Zn species are $93 \%$ free $\mathrm{Zn}^{2+}$ and $6 \% \mathrm{ZnSO}_{4}$. At $\mathrm{pH} 7.0$, they are $86 \%$ free $\left.\mathrm{Zn}^{2+}, 6 \% \mathrm{ZnSO}_{4}, 1 \% \mathrm{ZnB}(\mathrm{OH})_{4}\right)$ and $6 \%$ precipitated $\mathrm{Zn}$-phosphate.

\section{Changes in cation exchange capacity of roots (CECR) of tobacco}

The cation exchange capacity of the roots (CECR) was determined at different times of the culture. It did not vary significantly between 0 and 14 days, and was comparable for the two genotypes (Figure 1a). The mean value for the two genotypes and all exposure durations was $32 \pm 3 \mathrm{cmol}_{\mathrm{c}} \mathrm{kg}^{-1}$. The ratio of Ca extractable by $\mathrm{CuSO}_{4}$ to the CECR (“Ca:CECR"), which corresponds to the fraction of the CECR occupied by $\mathrm{Ca}$, did not vary significantly (Fig. 1b). The concentration of $\mathrm{Ca}\left(\mathrm{NO}_{3}\right)_{2}$ being kept the same $(1.02 \pm 0.05 \mathrm{mM})$ in the preculture and culture solutions during the 14 days of culture, this steady-state was expected. Again, there was no significant difference between the two genotypes. Calcium accounted for $52 \pm 10 \%$ of the CECR (mean value for the two genotypes and all exposure durations). On the contrary, an increase in the fraction of the CECR occupied by Zn (“Zn:CECR”) was expected because Zn concentration increased from $0.5 \mu \mathrm{M}$ in the preculture to $100 \mu \mathrm{M}$ in the culture solution.

Cations exchange between the solution and roots is supposed to reach equilibrium within $48 \mathrm{~h}$ (Meychik et al., 2001). In our experiment, we observed a continuous increase in Zn:CECR during the 14 days of culture (Fig. 1b). At the end of the culture, the sum of Ca:CECR and Zn:CECR accounted for $90 \pm 5 \%$ of the CECR for A1, and $110 \pm 5 \%$ of the CECR for C5

299 Comparison of different sequential extractions of $\mathrm{Zn}$ accumulated in roots of tobacco 
300 The accumulation compartments of $\mathrm{Zn}$ in A1 tobacco roots exposed to $100 \mu \mathrm{M} \mathrm{Zn}$ for 4 days

301 (culture $\mathrm{n}^{\circ}$ 2) were studied by chemical extractions (Fig. 2). Various procedures were

302 compared : (i) $10 \mathrm{mM} \mathrm{CuSO}_{4}$, then $100 \mathrm{mM} \mathrm{HCl}$, (ii) three successive extractions with 10

$303 \mathrm{mM} \mathrm{CuSO}_{4}$, then $100 \mathrm{mM} \mathrm{HCl}$, (iii) pure water, then $10 \mathrm{mM} \mathrm{CaCl}_{2}$, and (iv) $10 \mathrm{mM}$ EDTA.

304 Each procedure was done at $4^{\circ} \mathrm{C}$ and $25^{\circ} \mathrm{C}$ to evaluate the role of active $\mathrm{Zn}$ transport during

305 the treatments. Chemical extractions on whole roots and isolated cell walls of roots were

306 compared to distinguish the intra- and extra-cellular contributions.

307 On whole roots, water extracted about $20 \%$ of total $\mathrm{Zn}$, and the $\mathrm{CaCl}_{2}$ solution removed

308 another $20 \%$. The one-step extraction with $\mathrm{CuSO}_{4}$ yielded similar results as the water $+\mathrm{CaCl}_{2}$

309 extraction ( $40 \pm 8 \%$ and $39 \pm 5$ respectively). The three-step $\mathrm{CuSO}_{4}$ and the EDTA extraction

310 were slightly more efficient ( $52 \pm 4 \%$ and $55 \pm 9 \%$ of total $\mathrm{Zn}$, respectively). These data are

311 consistent with the occurrence of a distribution of affinity sites. The results obtained at $4{ }^{\circ} \mathrm{C}$

312 and $25^{\circ} \mathrm{C}$ were roughly similar except for the $\mathrm{HCl}$ treatment (extraction doubled at $25^{\circ} \mathrm{C}$

313 compared to $4^{\circ} \mathrm{C}$ ). This suggests that $\mathrm{Zn}$ transport through the cell membranes during the

314 water, $\mathrm{CaCl}_{2}, \mathrm{CuSO}_{4}$, and EDTA extractions was insignificant. This result also suggests that

315 cation diffusion within the roots is not significantly different at $4{ }^{\circ} \mathrm{C}$ and at $25^{\circ} \mathrm{C}$. In contrast,

$316 \mathrm{HCl}$ extractant is likely resulting in some damage of the integrity of cell membranes and

317 thereby in the release of intracellular $\mathrm{Zn}$, as suggested for $\mathrm{Cu}$ by Iwasaki et al. (1990).

319 Results obtained on the isolated cell walls also suggested a distribution of affinity sites.

$320 \mathrm{Zn}$ extractability was higher for the isolated cell walls than for the whole roots (73 to $96 \%$

321 compared to 39 to $55 \%$ ).

322

323 Determination of Zn speciation in tobacco roots 
324 First, in order to give an idea of the sensitivity of EXAFS spectroscopy, Figure 3 shows the

325 spectra for various $\mathrm{Zn}$ reference compounds of interest for this study. The spectrum for $\mathrm{Zn}$ -

326 oxalate dihydrate presents a characteristic shoulder between 6.1 and $6.6 \AA^{-1}$. It is due to the

327 well ordered structure of this organic compound, $\mathrm{Zn}$ being bound to four carboxyl groups in a

328 planar configuration (Fig. 3). Citrate, malate and pectin contain hydroxyl and carboxyl

329 functional groups. The spectrum for Zn-citrate exhibits a weakly pronounced shoulder around

$3306.5 \AA^{-1}$, and the spectrum for $\mathrm{Zn}$-malate is even smoother. This reflects an increase in disorder

331 from $\mathrm{Zn}$-oxalate to $\mathrm{Zn}$-citrate, and from $\mathrm{Zn}$-citrate to $\mathrm{Zn}$-malate. The spectra for $\mathrm{Zn}$-pectin

332 and for Zn-cell walls at various $\mathrm{Zn}$ concentrations present strong similarities with Zn-malate,

333 which suggests a similar Zn local structure. Thus, in the cell walls and in Zn-pectin, the metal

334 is probably bound to hydroxyl and carboxyl groups. The spectra for Zn-cellulose (recorded in

335 freeze-dried and hydrated state) have a markedly higher frequency relative to Zn-pectin, and

336 present some similarities with aqueous $\mathrm{Zn}^{2+}$. This suggests an outer-sphere configuration, i.e.,

337 Zn being fully hydrated and bound to cellulose through weak interactions. This is consistent

338 with the fact that cellulose contains hydroxyl groups only, and that these groups are fully

339 protonated at $\mathrm{pH}$ 5.0, and deprotonate in alkaline conditions $(\mathrm{pH}>10)$ (Smith and Martell,

340 1982). The structural parameters for $\mathrm{Zn}$ first coordination shell in these compounds were

341 determined. For Zn-cell walls and Zn-pectin, Zn-O distances were 1.99 and $2.00 \AA$,

342 respectively (Table 2). Considering typical $\mathrm{Zn}-\mathrm{O}$ distances for tetrahedral and octahedral

343 coordination (1.95 to 2.0 and 2.0 to $2.2 \AA$, respectively, Sarret et al., 1998), this suggests that

344 the metal occupies both types of coordination sites in these samples. For Zn-cellulose, a Zn-O

345 distance of $2.07 \AA$ was found, indicating an octahedral coordination. Figure 3 also shows the

346 spectra for an inorganic and organic Zn-phosphate, Zn-sorbed hydroxylapatite and Zn-

347 phytate, respectively. $\mathrm{Zn}$ is in tetrahedral coordination in both compounds (Table 2). The

348 similarity between the two spectra suggests that it may be difficult to distinguish between 
349 mineral and organic Zn-phosphate, especially in case of a mixture of $\mathrm{Zn}$ species. Finally,

350 figure 3 shows the spectrum for $\mathrm{Zn}$-sorbed ferrihydrite, which is used as a proxy for $\mathrm{Zn}$ in

351 ferritin (Briat and Lebrun, 1999).

352 Figure 4 presents the spectra for the whole roots of A1 and C5 genotype tobacco grown

353 on agarose, ferrihydrite and hectorite substrates (culture $\left.n^{\circ} 4\right)$. They present slight differences

354 in frequency and shape of the oscillations. For instance, some of them exhibit a shoulder on

355 the second oscillation similar to (but less pronounced than) Zn-oxalate dihydrate. This feature

356 suggests that $\mathrm{Zn}$-oxalate might be present as a minor species. Because of the limited number

357 of spectra, principal component analysis could not be used, and spectra were simulated by

358 linear combinations of reference spectra (Table 2). A combination of two to three components

359 was sufficient to provide satisfactory fits, and four-component fits did not decrease

360 normalized sum-squares (NSS, formula given in Table 2$)$ significantly $(<5 \%)$. As anticipated,

361 Zn-oxalate was identified, and represented up to $30 \%$ of total $\mathrm{Zn}$ in some whole roots. For

362 these samples, unsatisfactory fits were obtained if Zn-oxalate was removed from the set of

363 references (NSS increased by more than 10\%). For technical reasons, oxalate concentration

364 was not measured in the roots studied by EXAFS, but in the whole roots of A1 genotype

365 tobacco grown on a $\mathrm{Zn}$-free medium (Table 3). This concentration (497 $\mathrm{mmol} \mathrm{kg}^{-1}$ ) was by far

366 sufficient to explain the highest Zn-oxalate concentration determined by EXAFS (8.2 mmol

$367 \mathrm{~kg}^{-1}$ for the A1 genotype tobacco grown in the agarose medium, value obtained by

368 multiplying the molar percentage of $\mathrm{Zn}$ oxalate determined by EXAFS with the total $\mathrm{Zn}$

369 concentration in the roots).

370 The second (and most represented) Zn species identified was Zn-pectin and/or Zn-

371 malate. The similarity between the two EXAFS spectra prevents the positive identification of

372 one or the other compound (see above). Whole roots do contain malate (Table 3). However,

373 they are richer in oxalate and citrate (Table 3), and these two organic acids have a higher 
374 affinity for $\mathrm{Zn}$ than malate ( $\log \mathrm{K}=4.0$ for $\mathrm{Zn}$ oxalate, and 4.9 for $\mathrm{Zn}$ citrate, compared to 2.9

375 for Zn malate, Smith and Martell, 1982). Therefore, the presence of Zn-malate as major Zn

376 species is unlikely in these root samples. Zn-pectin which can be used as a proxy for Zn-cell

377 walls (see above) is more likely. Because of the similarity between Zn-pectin, Zn-malate and

$378 \mathrm{Zn}$-citrate, this pool may contain a minor proportion of complexes of $\mathrm{Zn}$ with simple organic

379 acids complexes: it is referred to as "Zn-COOH/OH" in Table 2.

380 The third species identified was Zn-phosphate. Depending on the samples, this pool was

381 simulated by mineral (Zn-sorbed hydroxylapatite and parahopeite) or organic (Zn-phytate)

382 references. Although this species was the least abundant in the whole roots, unsatisfactory fits

383 were obtained if Zn-phosphate references were removed from the set of references (NSS

384 increased by more than $10 \%$ ). As explained above, it was not possible to conclude on the

385 exact nature of $\mathrm{Zn}$-phosphate. Finally, the $\mathrm{Zn}$-sorbed ferrihydrite reference, used as a proxy

386 for $\mathrm{Zn}$ incorporated in ferritin, did not show up it the simulations, suggesting that this species

387 was insignificant.

388 Table 2 summarizes the results of EXAFS analyses and shows that the "Zn-COOH/OH" 389 pool was the major species ( 43 to $80 \%$ of total $\mathrm{Zn}$ depending on the root sample), followed by $390 \mathrm{Zn}$-oxalate (0 to $30 \%$ ) and $\mathrm{Zn}$-phosphate (0 to $16 \%)$.

392 In order to get some insights on the localization of these three $\mathrm{Zn}$ species, whole roots 393 before and after extraction with $\mathrm{CuSO}_{4}$ and $\mathrm{CuSO}_{4} / \mathrm{HCl}$ were studied by EXAFS 394 spectroscopy (Fig. 4 and Table 2). For this purpose, whole roots of C5 genotype tobacco were 395 grown in hydroponics containing $200 \mu \mathrm{M}$ Zn were used (culture $\mathrm{n}^{\circ} 3$, chemical extraction 396 experiment in Table 2). The speciation of $\mathrm{Zn}$ in this nutrient solution was similar to the one 397 calculated for the $100 \mu \mathrm{M} \mathrm{Zn}$ solution, with $92 \%$ free $\mathrm{Zn}^{2+}$ and $6 \% \mathrm{ZnSO}_{4}$ at $\mathrm{pH} 5.5$, and $88 \%$ 398 free $\left.\mathrm{Zn}^{2+}, 7 \% \mathrm{ZnSO}_{4}, 1 \% \mathrm{ZnB}(\mathrm{OH})_{4}\right)$ and $3.5 \%$ of precipitated $\mathrm{Zn}$-phosphate at $\mathrm{pH}$ 7.0. For 
399 the untreated roots, the distribution of $\mathrm{Zn}$ species was comparable to what was found for 400 plants grown in solid substrates. Roots contained $81 \pm 4 \% \mathrm{Zn}-\mathrm{COOH} / \mathrm{OH}, 6 \pm 4 \% \mathrm{Zn}$ 401 oxalate, and $6 \pm 4 \% \mathrm{Zn}$-phosphate. By multiplying these percentages with $\mathrm{Zn}$ total root 402 concentration, one obtains the molar concentration of $\mathrm{Zn}$ for each species, i.e., $39.9 \pm 1.9,3.0$ $403 \pm 2.0$ and $3.0 \pm 2.0 \mathrm{mmol} \mathrm{Zn} \mathrm{kg}^{-1}$, respectively. In the $\mathrm{CuSO}_{4}-$ extracted roots, the proportion 404 of $\mathrm{Zn}-\mathrm{COOH} / \mathrm{OH}$ species was decreased to $72 \pm 10 \%\left(23.3 \pm 3.2 \mathrm{mmol} \mathrm{Zn} \mathrm{kg}^{-1}\right)$. The $\mathrm{Zn}$ 405 phosphate species identified in the untreated roots was absent, and the change in Zn-oxalate 406 concentration was within experimental error. These results indicate that the $\mathrm{CuSO}_{4}$ extraction 407 removed all of the $\mathrm{Zn}$-phosphate pool, about half of the $\mathrm{Zn}-\mathrm{COOH} / \mathrm{OH}$ pool, but did not alter 408 the Zn-oxalate pool.

409 The spectrum for the residues after the $\mathrm{HCl}$ extractions strongly differed from the other

410 root spectra, and could not be simulated by the three reference spectra used before. Its

411 frequency was intermediate between the untreated root spectrum and the Zn-cysteine, in

412 which $\mathrm{Zn}$ is bound to sulfur atoms. The first shell simulation showed that $\mathrm{Zn}$ was bound to 4.5

413 sulfur atoms at $2.28 \AA$, and 1.3 oxygen atoms at $2.13 \AA$ (Figure 5 and Table 2 ). The presence

414 of sulfur atomic neighbours might suggest the binding of $\mathrm{Zn}$ by glutathione, phytochelatins or 415 metallothioneins. However, considering $\mathrm{Zn}$ concentration in the $\mathrm{HCl}$-extracted roots (14.00

$\left.416 \mathrm{mmol} \mathrm{kg}{ }^{-1}\right)$ and the $\mathrm{CuSO}_{4}$-extracted roots $\left(32.31 \mathrm{mmol} \mathrm{kg}^{-1}\right), \mathrm{S}$ neighbours should have been 417 detected in the $\mathrm{CuSO}_{4}$-extracted roots. As this was not the case, it is concluded that some 418 redistribution of $\mathrm{Zn}$ occurred during the $\mathrm{HCl}$ extraction. Thus, this acidic treatment, which 419 was supposed to desorb $\mathrm{Cu}$ from the cell walls, probably damaged a breakage of cellular 420 membranes and induced the subsequent release of intracellular proteins, leading to the 421 formation of $\mathrm{Zn}-\mathrm{S}$ bonds. Note that this artefact was not observed for $\mathrm{CuSO}_{4}-$ extracted roots.

\section{Discussion}


Concentrations of $\mathrm{Zn}$ in shoots and roots of crop species exposed to high $\mathrm{Zn}$

425

426

concentration are highly variable (Table 4). In crop species grown in similar conditions of $\mathrm{Zn}$ exposure, $\mathrm{Zn}$ shoots concentration ranged between 1 and $19 \mathrm{mmol} \mathrm{\textrm {kg } ^ { - 1 }}$ and $\mathrm{Zn}$ roots concentration ranged between 5 and $150 \mathrm{mmol} \mathrm{kg}^{-1}$ (Fargasova et al., 2001; van Steveninck et al., 1993; Fontes and Cox, 1998; Brune et al., 1994). With a concentration of $15-16 \mathrm{mmol} \mathrm{kg}{ }^{-1}$ and 74-99 $\mathrm{mmol} \mathrm{kg}^{-1}$, tobacco appears as a crop species with high $\mathrm{Zn}$ uptake capacity. Similar Zn concentrations were observed in shoots and roots of the wild species Silene vulgaris (Harmens et al., 1993; Chardonnens et al., 1998) and of the hyperaccumulator Arabidopsis halleri (Zhao et al., 2000). Higher Zn concentrations were measured in the shoots of the hyperaccumulator Thlaspi caerulescens and of the non hyperaccumulator Thlaspi ochroleucum regardless of $\mathrm{Zn}$ exposure (Shen et al., 1997).

The roots of the $\mathrm{C} 5$ genotype of tobacco accumulated more $\mathrm{Zn}$ than those of the A1 genotype, as shown by Vansuyt et al. (2000) in a pot culture. In the C5 genotype, the overexpression of ferritin induced a decrease in physiologically available iron, and an activation of the mechanisms of iron uptake. Ferritin was thus a possible candidate for $\mathrm{Zn}$ storage in the C5 genotype plants. However, no Zn-ferrihydrite association was found in C5 roots.

Results of CECR showed a continuous increase in Zn:CECR during the culture, the sum of Ca:CECR and Zn:CECR being close to $100 \%$ of the CECR after 14 days of culture. Three interpretations can be proposed. Firstly, all cations originally occupying the CECR except Ca might be progressively replaced by Zn. This seems unlikely. Secondly, part of intracellular Zn might be released, either by active transport or by damage of the membrane during the $\mathrm{CuSO}_{4}$ extraction. The temperature had no effect on $\mathrm{Zn}$ extraction by $\mathrm{CuSO}_{4}$, thus invalidating the possible role of an active transport. The efficiency of the $\mathrm{CuSO}_{4}$ extraction was comparable to the extraction with water and then $\mathrm{CaCl}_{2}$, which are supposed to preserve the membrane 
integrity. Moreover, EXAFS did evidence a damage of the membranes for the HCl-treated roots, not for the $\mathrm{CuSO}_{4}$-extracted ones. Therefore, the second hypothesis can be ruled out. Thirdly, $\mathrm{CuSO}_{4}$ may solubilize some $\mathrm{Zn}$ precipitated in the apoplasm. This hypothesis is supported by EXAFS results. In order to avoid (or at least to limit) this precipitation of $\mathrm{Zn}$, next experiments were performed on roots after only 4 days of exposure to $\mathrm{Zn}$ (i.e., when $\mathrm{Zn}$ occupies about $10 \%$ of the CECR).

Results of the chemical extractions on whole roots and on isolated cell walls evidenced a distribution of $\mathrm{Zn}$ affinity sites, from the least to the most strongly bound $\mathrm{Zn}$ : (i) soluble in water, (ii) extractable by $\mathrm{CaCl}_{2}$ or by $\mathrm{CuSO}_{4}$ in one step, (iii) extractable by EDTA or by $\mathrm{CuSO}_{4}$ in three steps, and finally (iv) non-exchangeable $\mathrm{Zn}$. In whole roots, this latter pool represented 45 to $48 \%$ of total root $\mathrm{Zn}$ and may include intracellular $\mathrm{Zn}$, and extracellular $\mathrm{Zn}$ bound to high affinity sites or precipitated. In isolated cell walls, strongly bound $\mathrm{Zn}$ accounted for a small fraction (4 to 5\%) of Zn, as observed for Thlaspi caerulescens (Lasat et al., 1998) and wheat (Hart et al., 1998).

\section{The EXAFS analyses of tobacco roots showed that zinc was predominantly bound to} $\mathrm{COOH} / \mathrm{OH}$ groups (40 to $80 \%$ of total root $\mathrm{Zn}$ ). Only half of this pool was $\mathrm{CuSO}_{4}{ }^{-}$ exchangeable. The second half might correspond to strong $\mathrm{Zn}$-cell wall complexes and/or to intracellular complexes with organic acids such as citrate and malate. Zn oxalate was found as a minor component ( 0 to $30 \%$ of total $\mathrm{Zn}$ ). It was not affected by the $\mathrm{CuSO}_{4}$ treatment, which suggests an intracellular localization. Oxalate was observed as free anion and as Ca-oxalate crystals in the vacuoles of tobacco leaves (Wang et al., 1992, Bouropoulos et al., 2001). Caoxalate crystals are also excreted through the trichomes of tobacco (Sarret et al., 2006). The role of oxalate in the detoxification of $\mathrm{Zn}$ in fungi and lichens is well known (Dutton and Evans, 1996, Adamo and Violante, 2000). In higher plants, oxalate has been shown to 
474 detoxify $\mathrm{Al}, \mathrm{Sr}, \mathrm{Pb}$ and $\mathrm{Cu}$ (Franceschi and Nakata, 2005). The present study suggests a role

475 in $\mathrm{Zn}$ detoxification. $\mathrm{Zn}$-phosphate was present as a minor component in whole roots (0 to

$47616 \%$ of total $\mathrm{Zn}$ ). This species has been observed on the surface roots in hydroponics (Küpper

477 et al., 2000, Sarret et al., 2002), and inside the root cells of several crop species (Van

478 Steveninck et al., 1994). In the present case, $\mathrm{Zn}$-phosphate was removed by $\mathrm{CuSO}_{4}$ thus

479 suggesting an extracellular location. No relationship could be drawn between the distribution

480 of $\mathrm{Zn}$ species and $\mathrm{Zn}$ total concentration, plant genotype or to the composition of the growing

481 medium. Moreover, a relatively large dispersion in the percentages of $\mathrm{Zn}$ species was

482 observed between the samples. Further investigations are necessary to better interpret these 483 observations.

484 Because of the low Zn concentration of the roots EXAFS spectra could not be recorded

on hydrated samples, but on freeze-dried materials. The structure of the $\mathrm{Zn}$-cell wall complexes and Zn-phosphate precipitates should not be affected by this dehydrating treatment (Guiné et al., 2006). At the opposite, Zn-organic acid complexes present in solution are likely to be precipitated by the freeze-drying treatment. Considering the one identified in this study (Zn-oxalate), results should not be affected though: indeed the spectra for solid Zn-oxalate dihydrate and Zn-oxalate in solution are similar (Sarret et al., 1998). The occurrence of free $\mathrm{Zn}^{2+}$ may be overlooked due to the freeze-drying treatment. However, $\mathrm{Zn}^{2+}$ is unlikely to be present in significant amount in the cell walls and inside the cells because of the high concentration of ligands in these compartments. Free $\mathrm{Zn}^{2+}$ was observed in the xylem sap of a hyperaccumulating plant (Salt et al., 1999). However, xylem sap certainly accounts for a minor fraction of total root $\mathrm{Zn}$. Therefore, the freeze-drying treatment should not modify significantly the distribution of $\mathrm{Zn}$ species in the roots.

In conclusion, the combination of chemical extractions and EXAFS spectroscopy, generally used for the study of soils and sediments, proved as an interesting approach for 
499 plants. It overcame the relatively low sensitivity of EXAFS for organic complexes and for

500 mixed species, and enabled the identification of intracellular and extracellular $\mathrm{Zn}$ species.

501 Among our findings, Zn-phosphate was found in the apoplasm of the tobacco roots although

502 the $\mathrm{P}$ concentration in culture solution was $5 \mu \mathrm{M}$ only, and intracellular $\mathrm{Zn}$ oxalate was

503 identified in these roots.

504

505

\section{Acknowledgments}

506 This work was supported in part by the "Programme National de Recherche Sols et

507 Erosion" funded by CNRS and INRA, France. We would like to thank the ESRF for the

508 provision of beamtime. Zn cysteine reference spectrum was provided by S. Beauchemin. We

509 thank also Nicole Balsera, Denis Loisel and Michaël Clairotte from the UMR Rhizosphère \&

510 Symbiose team, and Nicolas Geoffroy, Martine Lanson and Delphine Tisserand from the

511 LGIT for their technical help.

\section{References}

514 Adamo, P., Violante, P., 2000. Weathering of rocks ad neogenesis of minerals associated with $515 \quad$ lichen activity. Appl. Clay Sci. 16, 229-256.

516 AOAC, 1975. Official methods of analysis. Washington DC, USA Association of official

517 analytical chemists

518 Beauchemin, S., Hesterberg, D., Nadeau, J. McGeer, J.C. 2004. Speciation of hepatic Zn in

519 trout exposed to elevated waterborne Zn using X-ray absorption spectroscopy. Environ.

$520 \quad$ Sci. and Technol. 38, 1288-1295.

521 Bouropoulos, N., Weiner, S., Addadi, L. 2001. Calcium oxalate crystals in tomato and 522 tobacco plants: Morphology and in vitro interactions of crystal-associated macromolecules.

523 Chem. Eur. J. 7(9), 1881-1888. 
524 Briat, J.F., Lebrun, M., 1999. Plant responses to metal toxicity. Comptes Rendus de

525 L'Academie des Sciences Serie III Sciences de la Vie 322, 43-54.

526 Brune, A., Urbach, W., Dietz, K.J. 1994. Compartmentation and transport of zinc in barley

527 primary leaves as basic mechanisms involved in zinc tolerance. Plant Cell Environ. 17,

$528 \quad 153-162$

529 Calba, H., Cazevieille, P. Jaillard, B., 1999. Modelling of the dynamics of Al and protons in

530 the rhizosphere of maize cultivated in acid substrate. Plant Soil. 209, 57-69.

531 Chardonnens, A.N., Ten Bookum, W.M., Vellinga, S., Schat, H., Verkleij, J.A.C., Ernst,

532 W.H.O., 1999. Allocation patterns of zinc and cadmium in heavy metal tolerant and

533 sensitive Silene vulgaris. J. Plant Physiol. 155, 778-787.

534 Dufey, J.E. Braun, R. 1986. Cation exchange capacity of roots: titration, sum of exchangeable

535 cations, copper adsorption. J. Plant Nutr. 9, 1147-1155.

536 Dufey, J.E., Genon, J.G., Jaillard, B., Calba, H., Rufyikiri, G. Delvaux, B. 2001. Cation

537 exchange on plant roots involving aluminium: experimental data and modeling. In: Trace

538 Elements in the Rhizosphere. (Eds). Gobran, G.R., Wenzel, W.W., Lombi, E.., pp. 228-

539 252. CRC Press LCC, Boca Raton, Florida, USA

540 Dutton, M.V. Evans, C.S. 1996. Oxalate production by fungi: Its role in pathogenicity and

541 ecology in the soil environment. Can. J. Microbiol. 42, 881-895

542 Ernst, W.H.O., Verkleij, J.A.C. Schat, H. 1992. Metal tolerance in plants. Acta Bot. Neerl. 41, $543 \quad 229-248$.

544 Fargasova, A. 2001. Phytotoxic effects of Cd, Zn, Pb, Cu and Fe on Sinapis alba L. seedlings 545 and their accumulation in roots and shoots. Biol. Plant. 44, 471-473.

546 Franceschi, V. Nakata, P. 2005. Calcium oxalate in plants: Formation and function. Annu.

547 Rev. Plant. Biol. 56, 41-71. 
548 Franco, C.R., Chagas, A.P. Jorge, R.A. 2002. Ion-exchange equilibria with aluminium

549 pectinates. Colloids Surface A 204, 183-192.

550 Fontes, R.L.F., Cox, F.R. 1998. Zinc toxicity in soybean grown at high iron concentration in $551 \quad$ nutrient solution. J. Plant Nutr. 21,1723-1730.

552 Guiné, V., Spadini, L., Sarret, G., Muris, M., Delolme, C., Gaudet, J.P., Martins, J., 2006.

553 Zinc sorption to three gram-negative bacteria: Combined titration, modeling and EXAFS 554 study. Environ Sci. Technol. ASAP.

555 Harmens, H., Gusmao, N.G.C.P.B., Hartog, P.R.d, Verkleij, J.A.C., Ernst, W.H.O., 1993.

556 Uptake and transport of zinc in zinc-sensitive and zinc tolerant Silene vulgaris. J. Plant $557 \quad$ Physiol. 141, 309-315.

558 Hart, J.J., Norvell, W.A., Welch, R.M., Sullivan, L.A., Kochian, L.V., 1998. Characterization

559 of zinc uptake, binding, and translocation in non extracted seedlings of bread and durum

$560 \quad$ wheat cultivars. Plant Physiol. 118, 219-226.

561 Haynes, R.J., 1980. Ion exchange properties of roots and ionic interactions within the root

562 apoplasm: their role in ion accumulation by plants. Bot. Review 46, 75-99.

563 Iwasaki, K., Sakurai, K., Takahashi, E., 1990. Copper binding by the root cell walls of Italian 564 ryegrass and red clover. Soil Sci. Plant. Nutr. 36,431-439.

565 Jumpertz, E. A. 1955. Über die Elektronendichteverteilung in der Zinkblende. Zeit. für 566 Elektrochemie 59, 419-425.

567 Küpper, H., Lombi, E., Zhao, F., McGrath, S.P., 2000. Cellular compartmentation of 568 cadmium and zinc in relation to other elements in the hyperaccumulator Arabidopsis 569 halleri. Planta 212, 75-84.

570 Lasat, M.M., Baker, A.J.M. Kochian, L.V., 1998. Altered Zn compartmentation in the root 571 symplasm and stimulated $\mathrm{Zn}$ absorption into the leaf as mechanisms involved in $\mathrm{Zn}$ 572 hyperaccumulation in Thlaspi caerulescens. Plant Physiol. 118, 875-883. 
573 Meychik, N., Yermakov, I.P., 2001. Ion exchange properties of plant root cell walls. Plant $574 \quad$ Soil 234, 181-193.

575 Monnet, F., Vaillant, N., Vernay, P., Coudret, A., Sallanon, H., Hitmi, A. 2001. Relationship

576 between PSII activity, CO2 fixation, and $\mathrm{Zn}, \mathrm{Mn}$ and $\mathrm{Mg}$ contents of Lolium perenne

577 under zinc stress, J. Plant Physiol. 158, 1137-1144.

578 Niebes, J.F., Hinsinger, P., Jaillard, B., Dufey, J.E., 1993. Release of nonexchangeable

579 potassium from different size fractions of two highly K-fertilized soils in the rhizosphere

580 of rape Brassica napus cv Drakkar. Plant Soil 155/156.

581 Nishizono, H., Ichikawa, H., Suziki, S. Ishii, F., 1987. The role of the root cell wall in the

582 heavy metal tolerance of Athyrium yokoscense. Plant Soil 101, 15-20.

583 Panfili, F., Manceau, A., Sarret, G., Spadini, L., Kirpichtchikova, T., Bert, V., Laboudigue,

584 A., Marcus, M., Ahamdach, N., Libert, M., 2005. The effect of phytostabilization on Zn

585 speciation in a dredged contaminated sediment using scanning electron microscopy, X-ray

586 fluorescence, EXAFS spectroscopy and principal components analysis. Geochim.

587 Cosmochim. Acta 69, 2265-2284.

588 Reed, A.T., Karipides, A., 1976. The crystal structure of S-Malatodiaquozinc(II) hydrate.

$589 \quad$ Acta Crystallogr. B32, 2085.

590 Rehr, J.J., Mustre de Leon, J., Zabinsky, S.I. Albers, R.C., 1991. Theoretical X-ray absorption

591 fine structure standards. J. Am. Chem. Soc. 113, 5135-5145.

592 Salt, D.E., Prince, R.C., Baker, A.J.M., Raskin, I., Pickering, I.J., 1999. Zinc ligands in the

593 metal hyperaccumulator Thlaspi caerulescens as determined using X-ray absorption

594 spectroscopy. Environ. Sci. Technol. 33, 713-717.

595 Salt, D.E., Prince, R.C., Pickering, I.J., 2002. Chemical speciation of accumulated metals in

596 plants: evidence from X-ray absorption spectroscopy. Microchem. J. 71, 255-259. 
Sarret, G., Harada, E., Choi, Y.E., Isaure, M.P., Geoffroy, N., Birschwilks, M., Clemens, S., Fakra, S., Marcus, M. A., Manceau, A., 2006. Trichomes of tobacco excrete zinc as Znsubstituted calcium carbonate and other Zn-containing compounds. Plant Physiol. 141, $1021-1034$

Sarret, G., Manceau, A., Spadini, L., Roux, J.C., Hazemann, J.L., Soldo, Y., Eybert-Bérard, L., Menthonnex, J.J., 1998. EXAFS determination of Pb, Zn complexing sites of Penicillium chrysogenum cell walls. Environ. Sci. Technol. 32, 1648-1655.

Sarret, G., Saumitou-Laprade, P., Bert, V., Proux, O., Hazemann, J.L., Traverse, A., Marcus M.A., Manceau, A., 2002. Forms of zinc accumulated in the hyperaccumulator Arabidopsis halleri. Plant Physiol. 130, 1815-1826. mineral nutrition. New Phytol.149,167-192.

610 hyperaccumulator Thlaspi caerulescens and the non-hyperaccumulator Thlaspi 611 ochroleucum, Plant Cell and Environ. 20, 898-906.

612 Smith, R.M., Martell, A.E., 1982, Critical Stability Constants. Plenum Press

613 Sposito, G., Coves, J., 1988. Soilchem: a computer program for the calculation of chemical 614 speciation in soils. The University of California.

615 Statistica édition 98, Kernel Version 5.1 M, StatSoft France 1984-1998, StatSoft Inc., Tulsa, 616 Oklahoma.

617 van Steveninck, R.F.M., Babare, A., Fernando D.R., van Steveninck, M.E. 1993. The binding 618 of zinc in root cells of crop plants by phytic acid. In: Plant nutrition - from genetic 619 engineering to field practice, Proceedings of the Twelfth International Plant Nutrition 620 Colloquium, 21-26 September 1993, 775-778, Perth, Western Australia. Kluwer 621 Academic Publishers, Dordrecht, Netherlands. 
622 Van Steveninck R. F. M., Barbare A., Fernando D. R., and Van Steveninck M. E. (1994) The

623 binding of zinc, but not cadmium, by phytic acid in roots of crop plants. Plant and Soil $624 \quad 167,157-164$.

625 Vansuyt, G., Mench, M., Briat, J.F., 2000. Soil dependent variability of leaf iron

626 accumulation in transgenic tobacco over expressing ferritin. Plant Physiol. Biochemi. 38, $627 \quad 499-506$.

628 Vasquez, M.D., Poschenrieder, C., Barcelo, J., Baker, A.J.M., Hatton, P., Cope, G.H., 1994.

629 Compartmentation of zinc in roots ans leaves of the zinc hyperaccumulator Thlaspi

630 caerulescens J\&C Presl. Bot. Acta 107, 243-250.

631 van Wuytswinkel, O., Vansuyt, G., Grignon, N., Fourcroy, P., Briat, J.F., 1999. Iron

632 homeostasis alteration in transgenic tobacco overexpressing ferritin. Plant J. 17, 93-97.

633 Wang, J., Evangelou, B.P., Nielsen, M.T., Wagner, G.J., 1992. Computer, simulated

634 evaluation of possible mechanisms for sequestering metal ion activity in plant vacuoles. II.

635 Zinc. Plant Physiol. 99, 621-626.

636 Wu, F.B., Dong, J., Qian, Q.Q., Zhang, G.P., 2005. Subcellular distribution and chemical

637 form of $\mathrm{Cd}$ and $\mathrm{Cd}-\mathrm{Zn}$ interaction in different barley genotypes. Chemosphere 60, 14376381446.

639 Zhao, F.J., Lombi, E., Breedon T., Mc Grath, S.P., 2000. Zn hyperaccumulation and cellular 640 distribution in Arabidopsis halleri. Plant Cell Environ. 23, 507-514. 
641 Table 1: Culture conditions and investigations

\section{Culture Growing medium Zn concentration Duration of Zn Genotype Investigations \\ number \\ in the medium \\ exposure (days)}

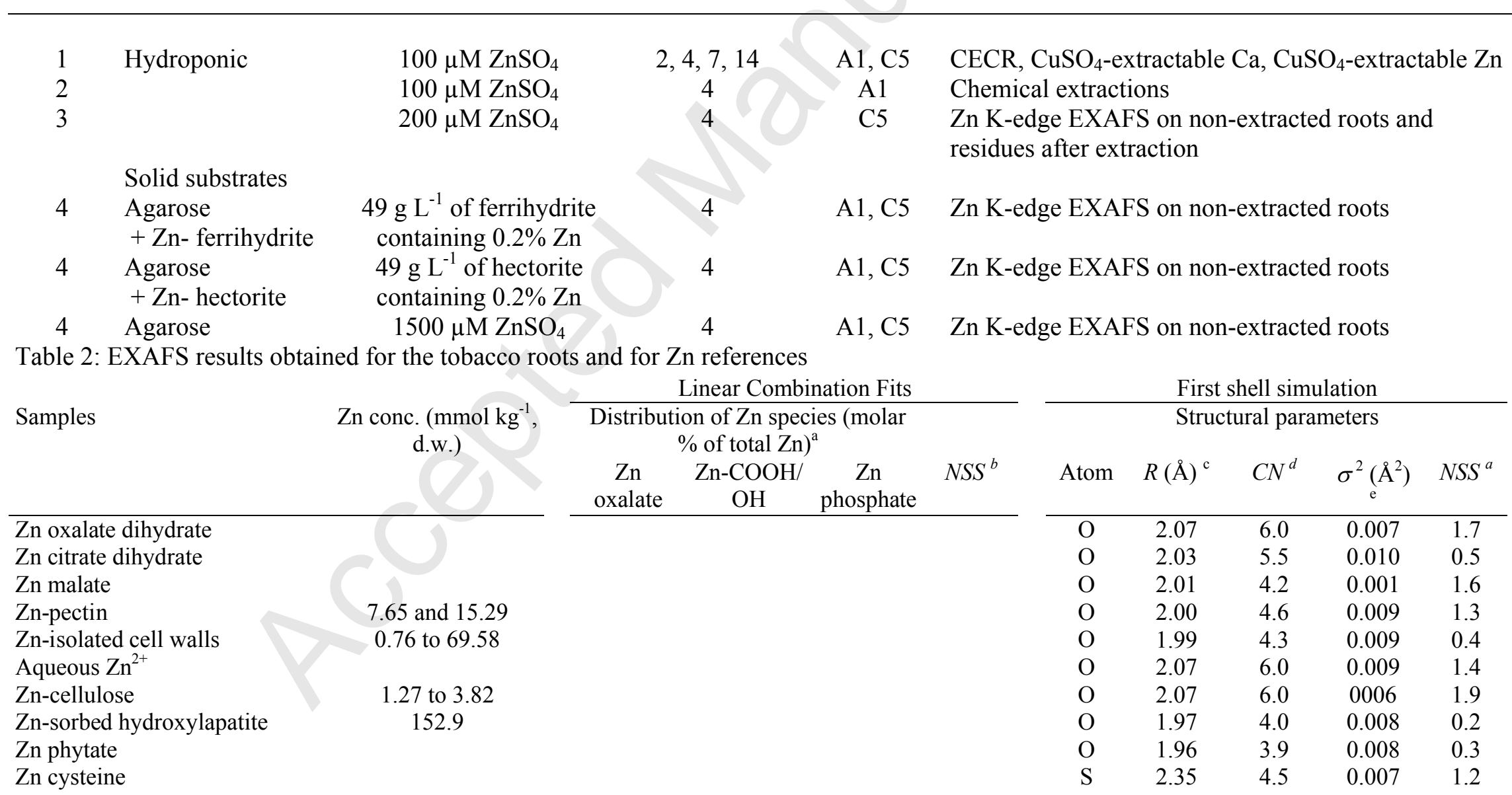

Genotype and growth medium 


\begin{tabular}{|c|c|c|c|c|c|c|c|c|c|c|}
\hline A1, agarose & 35.70 & $23 \pm 3$ & $69 \pm 4$ & 0 & 4.1 & $\mathrm{O}$ & 2.04 & 5.7 & 0.011 & 0.1 \\
\hline C5, agarose & 21.20 & 0 & $80 \pm 2$ & $16 \pm 2$ & 4.1 & $\mathrm{O}$ & 2.01 & 5.0 & 0.010 & 0.3 \\
\hline A1, ferrihydrite & 7.95 & $31 \pm 3$ & $51 \pm 11$ & $6 \pm 10$ & 8.7 & $\mathrm{O}$ & 2.05 & 6.0 & 0.011 & 1.1 \\
\hline C5, ferrihydrite & 5.21 & $30 \pm 4$ & $43 \pm 8$ & $13 \pm 6$ & 4.9 & $\mathrm{O}$ & 2.05 & 5.9 & 0.011 & 1.1 \\
\hline A1, hectorite & 2.11 & $23 \pm 3$ & $68 \pm 12$ & $14 \pm 19$ & 3.0 & $\mathrm{O}$ & 2.02 & 5.3 & 0.010 & 0.3 \\
\hline C5, hectorite & 2.05 & $17 \pm 3$ & $80 \pm 8$ & $12 \pm 5$ & 4.5 & $\mathrm{O}$ & 2.02 & 5.3 & 0.010 & 0.2 \\
\hline \multicolumn{11}{|c|}{ Chemical extraction experiment } \\
\hline C5, hydroponics & 49.23 & $6 \pm 4$ & $81 \pm 4$ & $6 \pm 4$ & 2.4 & $\mathrm{O}$ & 2.01 & 4.2 & 0.010 & 0.7 \\
\hline Same root, $\mathrm{CuSO}_{4}$-extracted & 32.31 & $20 \pm 6$ & $72 \pm 10$ & 0 & 3.7 & $\mathrm{O}$ & 2.02 & 4.7 & 0.010 & 1.3 \\
\hline Same root, $\mathrm{CuSO}_{4} / \mathrm{HCl}-$ & 14.00 & & & & & $\mathrm{O}$ & 2.11 & 1.4 & 0.006 & 8 \\
\hline extracted $^{e}$ & 14.00 & & & & & $\mathrm{~S}$ & 2.29 & 4.7 & 0.006 & \\
\hline
\end{tabular}

${ }^{\text {a }}$ Values expressed as mean \pm SD over the best fits, defined by a normalized sum-squares $(N S S)$ value comprised between the value obtained for the best simulation

$\left(N S S_{\text {best }}\right)$ and $1.1 \times N S S_{\text {best. }}{ }^{\mathrm{b}} N S S=\Sigma\left[k^{3} \chi(k)_{\text {exp }}-k^{3} \chi(k)_{\text {fit }}\right]^{2} / \Sigma\left[k^{3} \chi(k)_{\text {exp }}\right]^{2 *} 100 .{ }^{\mathrm{c}}$ Interatomic distance $(\AA) .{ }^{\mathrm{d}}$ Coordination number. ${ }^{e}$ Debye-Waller disorder factor $\left(\AA^{2}\right) .{ }^{\mathrm{f}}$

No satisfactory linear combination fit was obtained with the three components for this spectrum.

642 Table 3: Concentration of malate, oxalate and citrate in root of A1 genotype of tobacco.

Organic anion Concentration in roots

\begin{tabular}{lc} 
& $\left(\mathrm{mmol} \mathrm{kg}^{-1} \mathrm{DW}\right)$ \\
\hline Malate & $154 \pm 46$ \\
Oxalate & $497 \pm 56$ \\
Citrate & $187 \pm 37$ \\
\hline
\end{tabular}

643

644 Table 4: Concentration of $\mathrm{Zn}$ in shoot and root of other plant species grown in hydroponics

645

\begin{tabular}{lccccc}
\hline Plant species & $\begin{array}{l}\text { Exposure } \\
\text { duration, days }\end{array}$ & $\begin{array}{l}\text { Zn Concentration } \\
\text { in solution, } \mu \mathrm{M}\end{array}$ & $\begin{array}{l}\text { Zn Concentration in } \\
\text { shoots, mmol kg }{ }^{-1} \mathrm{DW}\end{array}$ & $\begin{array}{l}\text { Zn Concentration in } \\
\text { roots, mmol kg }{ }^{-1} \mathrm{DW}\end{array}$ & References \\
\hline White Mustard & 8 & 105 & 0.8 & 5 & from Fargosova, 2001 \\
Wheat & 8 & 100 & 4 & 59 & from van Steveninck et al., \\
& & & 14 & 79 & 1993 \\
Soybean & 14 & 10 & 22 & 132 & from Fontes and Cox, 1998 \\
Rye grass & 15 & 1000 & from Monnet et al., 2001
\end{tabular}


Barley

Barley

Silene vulgaris $\mathrm{Zn}$

sensitive / tolerant

Silene vulgaris $\mathrm{Zn}$

sensitive / tolerant

Thlaspi caerulescens

Thlaspi caerulescens

Thlaspi ochroleucum

Thlaspi ochroleucum

Arabidopsis halleri

Tobacco A1 / C5

$646 *$ Values of $\mathrm{Zn}$ concentration were read on graphs
10

400

100

150

10

500

10

500

100

100
10

145

$150 / 120$

$19 / 13$

$23 / 10$

46

431

31

215

31

$15 / 16$ from Brune et al., 1994 from Brune et al., 1994 after Harmens et al., 1993*

after Chardonnens et al., 1999*

after Shen et al., 1997* after Shen et al., 1997* after Shen et al., 1997* after Shen et al., 1997* after Zhao et al., 2000* this study 
647 Figure 1a. Variation of the cation exchange capacity of roots (CECR) for A1 and C5 648 genotype tobaccos. The horizontal line corresponds to the average CECR for A1 and C5. b. 649 Variation of the $\mathrm{CuSO}_{4}$-extracted $\mathrm{Ca}$ : CECR ratio (white bars) and of the $\mathrm{CuSO}_{4}$-extracted $650 \mathrm{Zn}$ : CECR ratio (hatched bars). For both graphs, tobacco were cultivated for 14 days in 651 hydroponics with $100 \mu \mathrm{M} \mathrm{ZnSO}_{4}$, and errors bars represent standard deviations.

652

653 Figure 2. Comparison of four types of sequential extractions at 4 and $25^{\circ} \mathrm{C}$ on roots of 654 tobacco cultivated for 4 days in hydroponics with $100 \mu \mathrm{M} \mathrm{ZnSO}_{4}(\mathrm{R})$, and at $25^{\circ} \mathrm{C}$ on isolated 655 root cell walls of tobacco incubated for 24 hours in hydroponics with $100 \mu \mathrm{M} \mathrm{ZnSO}_{4}(\mathrm{CW})$. 656 Res: residual $\mathrm{Zn}$. Values are normalized to $\mathrm{Zn}$ total content, which ranges between 45 and 69 $657 \mathrm{mmol} \mathrm{kg}^{-1}$ for the roots, and between 39 and $96 \mathrm{mmol} \mathrm{kg}^{-1}$ for the cell walls. Errors bars 658 represent standard deviations.

659

660 Figure 3. Zn K-edge EXAFS spectra for Zn reference compounds. Values in parentheses 661 indicate the $\mathrm{Zn}$ content, in $\mathrm{mmol} \mathrm{kg}{ }^{-1}$, dry weight.

662

663 Figure 4. Zn K-edge EXAFS spectra for some $\mathrm{Zn}$ reference compounds (Zn content, in mmol $664 \mathrm{~kg}^{-1}$, dry weight in parentheses), and for roots of A1 and C5 genotype tobacco grown on 665 artificial substrates and on hydroponics, and for the residues after the $\mathrm{CuSO}_{4}$ and $\mathrm{HCl}$ 666 treatment. Dashed lines are linear combination fits using reference spectra (proportions of the 667 species given in Table 2).

668

669 Figure 5. Fourier transformed EXAFS spectra for the untreated C5 root and for the residues 670 after chemical extraction and their first shell simulation (dotted lines, structural parameters 671 given in Table 2).

672

673 


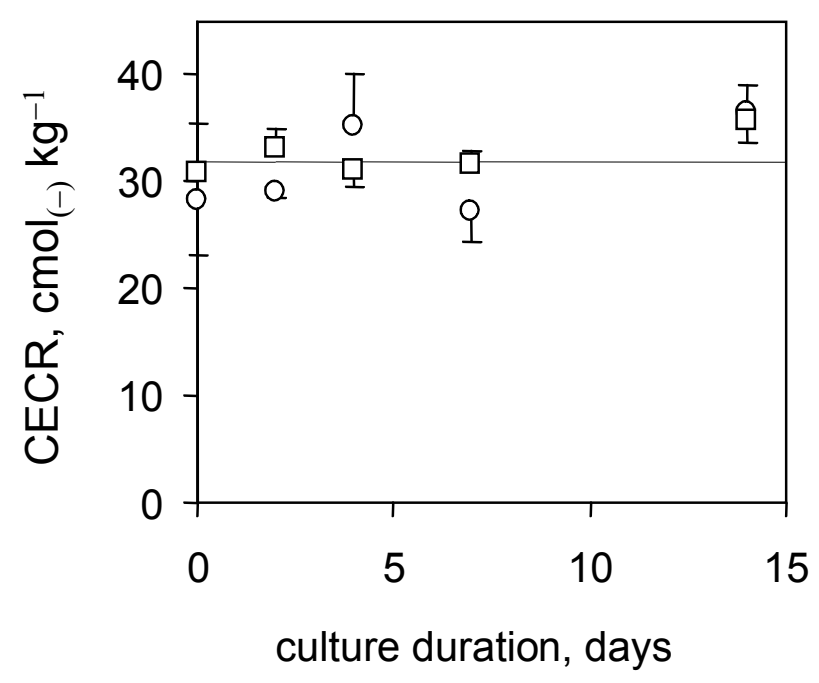

Figure 1a

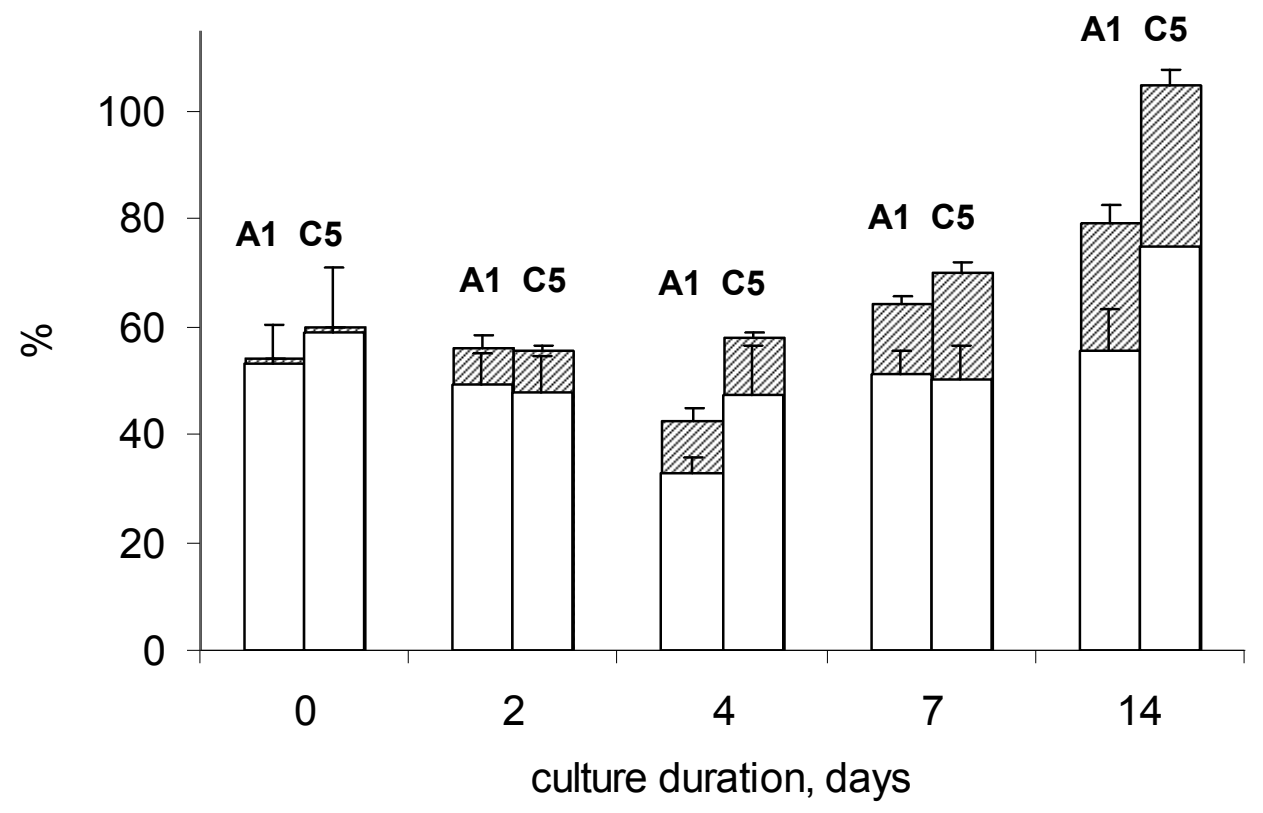

Figure 1b 
Figure 2

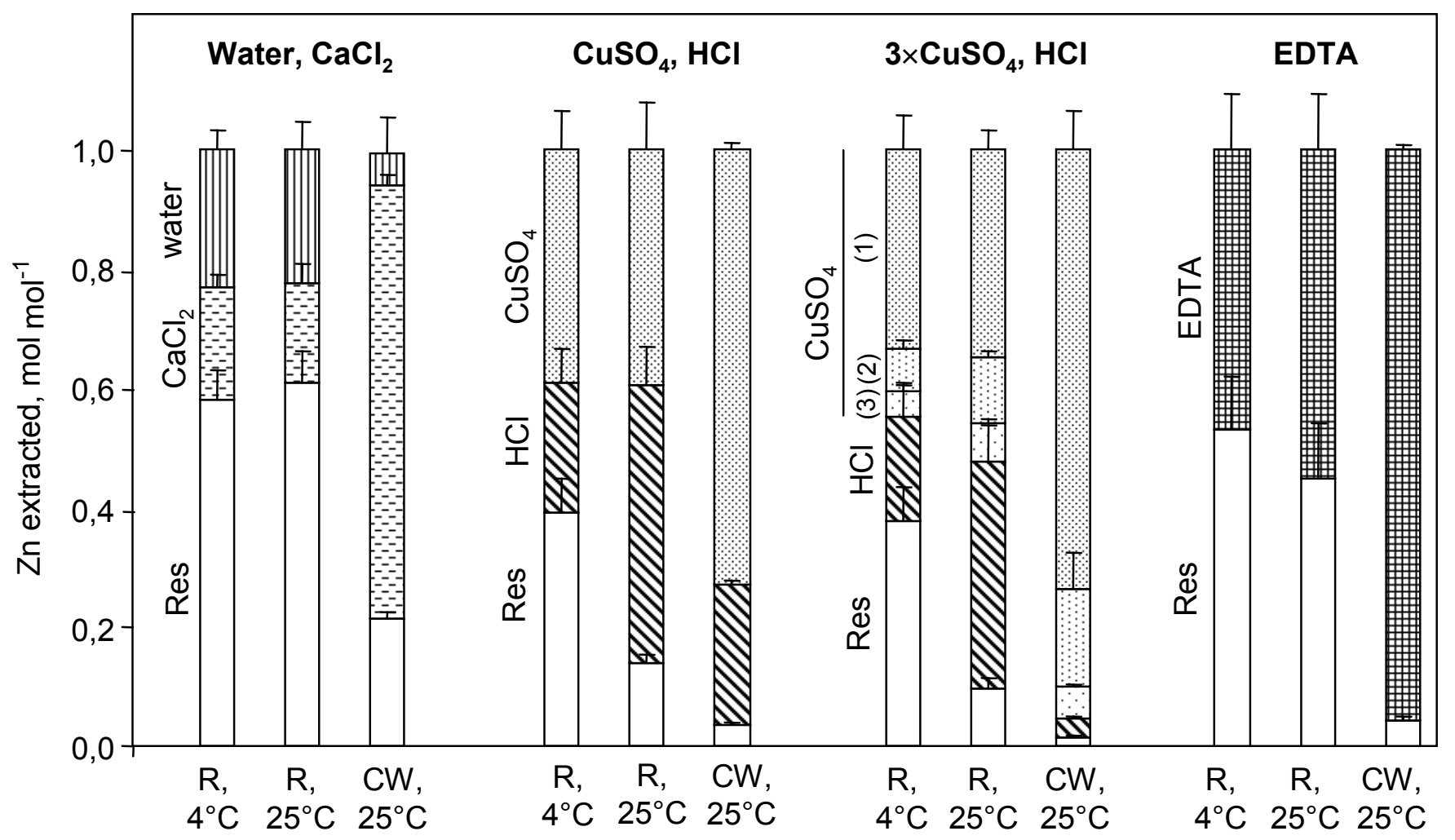




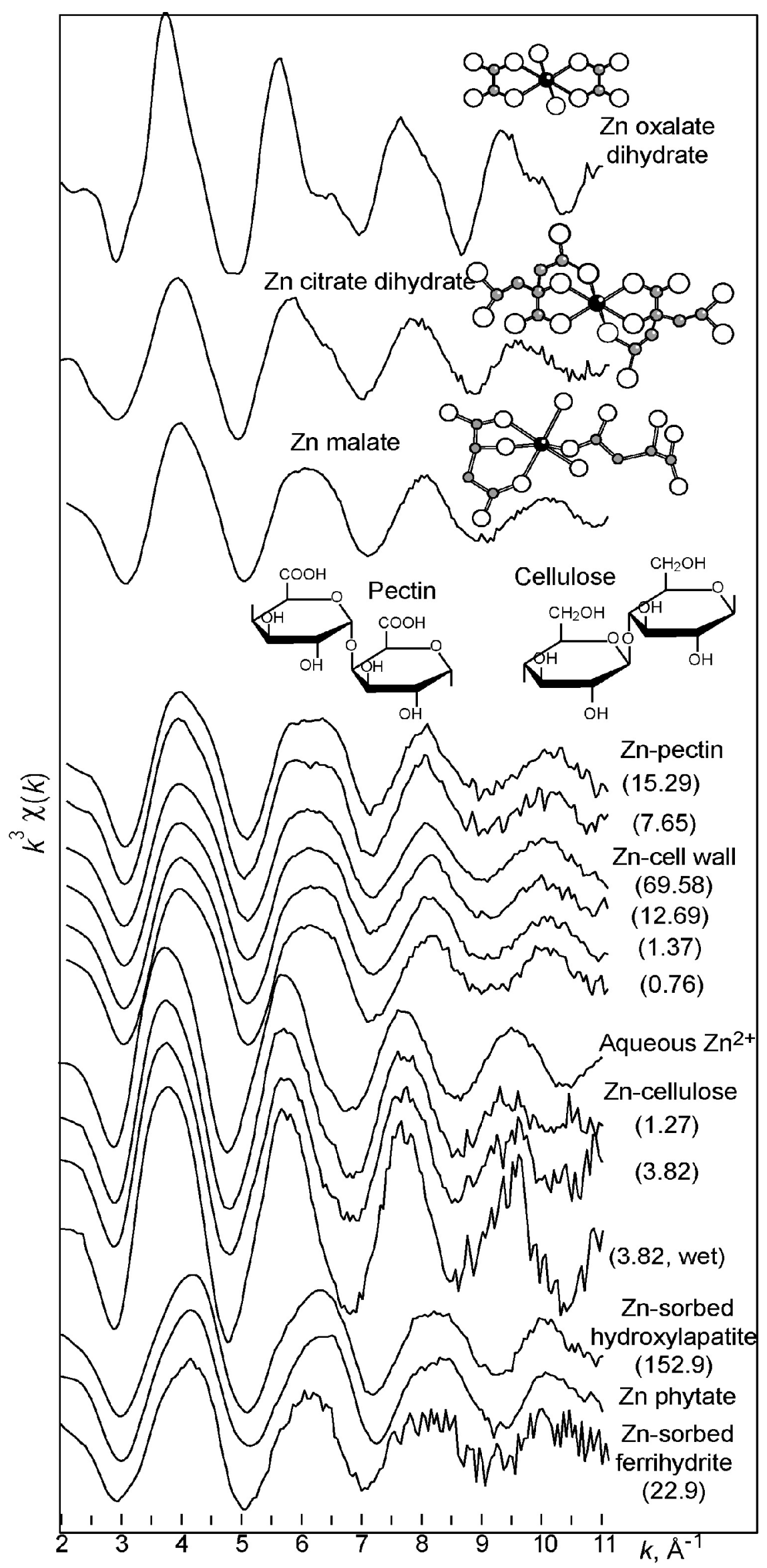

Figure 3 


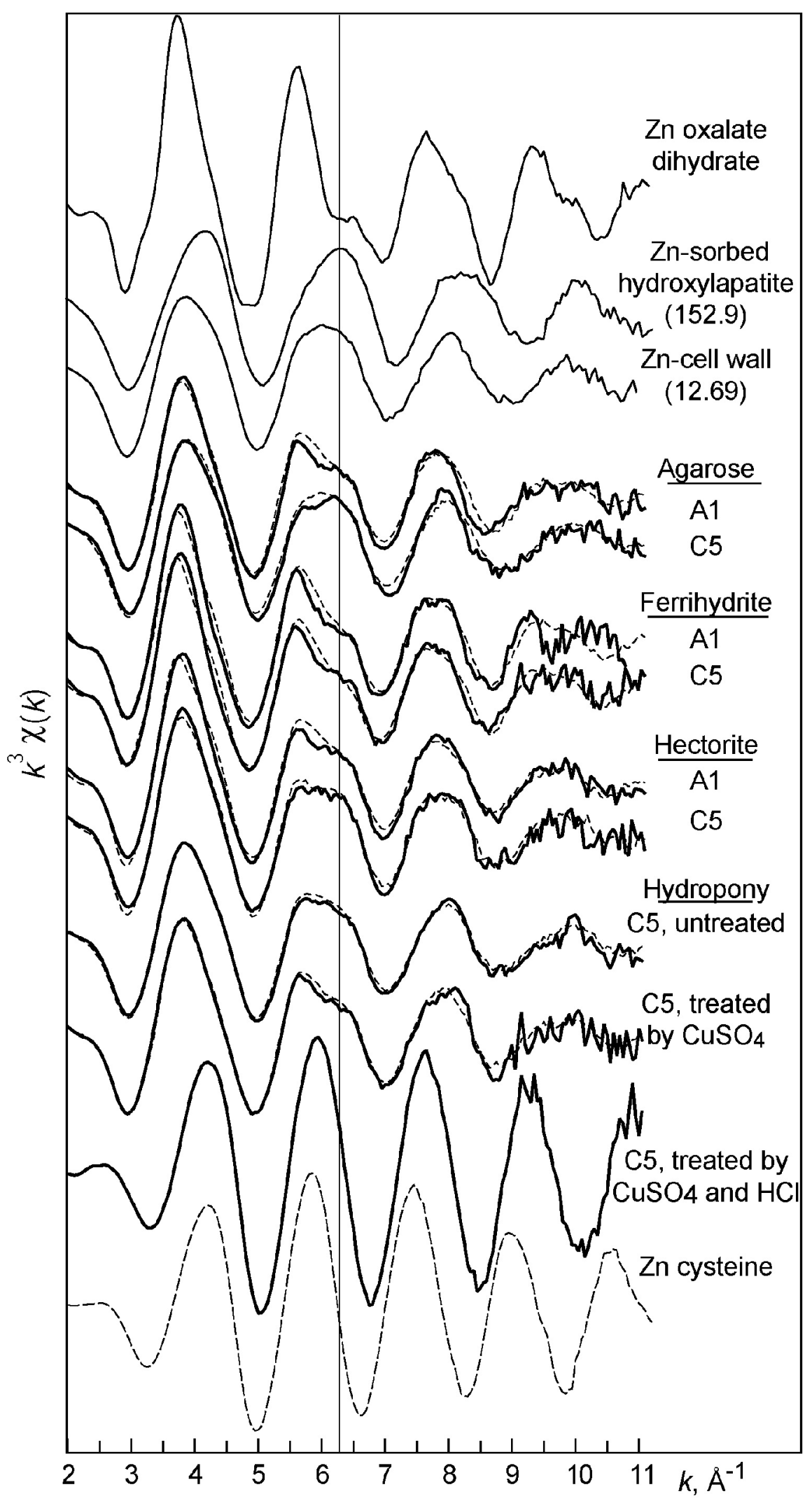

Figure 4 


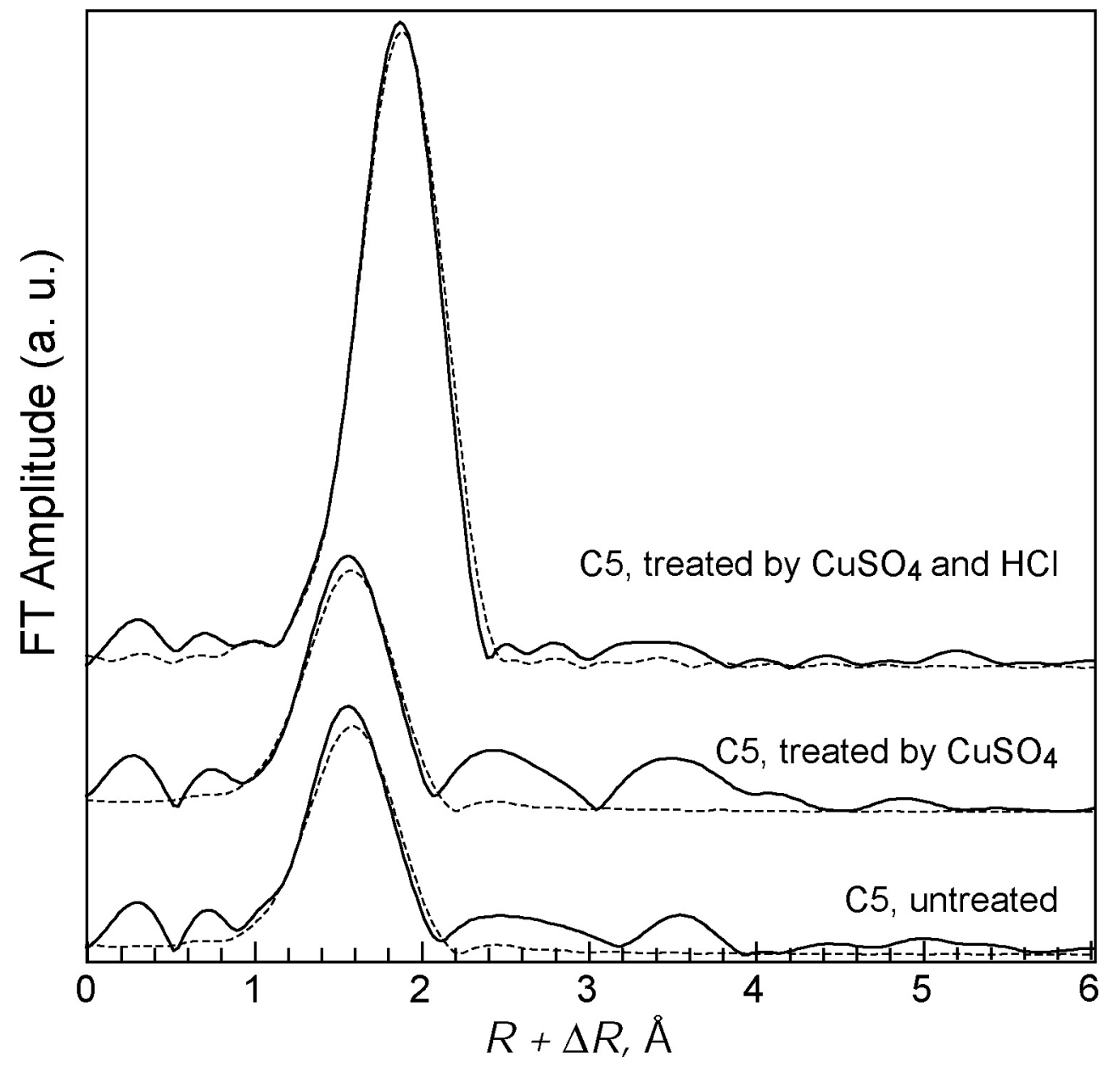

Figure 5 